\title{
Is the perinatal lethal form of Gaucher disease more common than classic type 2 Gaucher disease?
}

\author{
Deborah L Stone ${ }^{1}$, O tto P van Diggelen ${ }^{2}$, J ohannis BC de K lerk ${ }^{3}$, J ohannes LJ G aillard ${ }^{4}$, \\ Martinus $\mathrm{F}$ Niermeijer ${ }^{2}, \mathrm{R}$ ob Willemsen ${ }^{2}, \mathrm{~N}$ ahid Tayebi $^{1}{ }^{1}$ and E llen Sidransky ${ }^{1}$ \\ ${ }^{1}$ Clinical N euroscience B ranch, Intramural Research Program, $\mathrm{N}$ ational Institute of $\mathrm{M}$ ental $\mathrm{H}$ ealth, $\mathrm{N}$ ational \\ Institutes of $\mathrm{H}$ ealth, B ethesda, MD, USA \\ ${ }^{2} \mathrm{D}$ epartments of Clinical G enetics, ${ }^{3}$ Pediatrics, University H ospital, E rasmus U niversity, R otterdam \\ ${ }^{4}$ D epartment of Clinical Pathology, St Clara H ospital, Rotterdam, the N etherlands
}

\begin{abstract}
In recent years there has been increased recognition of a severe perinatal lethal form of $G$ aucher disease, the inherited deficiency of lysosomal glucocerebrosidase. We previously reported a case of severe type $2 \mathrm{G}$ aucher disease which was seen in a medical center in $R$ otterdam and now present three new cases from two other families seen at the same center. $M$ utational analyses of these cases revealed two novel mutations, H 311R and V 398F, located in exons $\mathbf{8}$ and $\mathbf{9}$, respectively. The identification of four cases of lethal type $\mathbf{2} \mathbf{G}$ aucher disease in a single center seems to be a function of increased awareness of this phenotype, rather than of geographic clustering. The actual incidence of lethal type $2 \mathrm{G}$ aucher disease may be underestimated, as many cases may have been misclassified as collodion babies or hydrops of unknown cause.
\end{abstract}

Keywords: Gaucher disease; lysosomal storage disorder; hydrops fetalis; collodion baby; mutation analysis

\section{Introduction}

A severe, perinatally lethal form of $G$ aucher disease, the inherited deficiency of the lysosomal enzyme, glucocerebrosidase (E C 3.2.1.45), has been delineated in the past decade. ${ }^{1-7}$ Three types of $\mathrm{G}$ aucher disease are recognized: type 1 or non-neuronopathic, type 2 or acute neuronopathic, and type 3 or subacute neuronopathic. Type 2 is the most rare and rapidly progressive

Correspondence: Ellen Sidransky, Clinical Neuroscience Branch, NIM H/NIH, Building 49, R oom B IE E 16, 49 Convent Drive MSC 4405, Bethesda, MD 20892-4405, USA. Tel: $3014960373 ; \quad F a x: 3014026438 ; \quad E-m a i l:$ sidranse@ irp.nimh.nih.gov

Received 8 October 1998; revised 18 December 1998; accepted 6 J anuary 1999 type and is classically diagnosed when an infant is several months old and has failure to thrive, hepatosplenomegaly and developmental delay. ${ }^{8} \mathrm{H}$ owever, the generation of a null allele knock-out mouse model of $\mathrm{G}$ aucher disease in $1992^{9}$ led to the identification of a more severe variant of $\mathrm{G}$ aucher disease. ${ }^{3}$ Homozygous null allele mice completely lack glucocerebrosidase activity, survive less than 12 hours, and have distinct epidermal abnormalities. ${ }^{9-10}$ These findings were subsequently appreciated in humans, and several dozen cases of severe perinatal $\mathrm{G}$ aucher disease have been described. One such case, a fetus delivered at 22 weeks of gestation to a first cousin couple in Rotterdam, presented with hydrops, dysmorphic features, and hepatosplenomegaly and had a complete absence of glucocerebrosidase activity. ${ }^{6}$ We now 
describe three additional cases of severe type 2 $\mathrm{G}$ aucher disease seen at the same medical center in R otterdam. G reater awareness of this dramatic phenotype may improve clinical recognition and permit timely genetic counseling.

\section{Case Reports}

\section{Case 1}

This female fetus was the first pregnancy of a consanguineous couple from Cape Verde. A hydropic, severely macerated fetus was delivered at 31 weeks of gestation. The birth weight was 780 grams, and hepatosplenomegaly was noted. The placenta weighed 540 grams, and the villi were coarse with markedly fibrotic stroma. A diagnosis of congenital syphilis was suspected, although this could not be confirmed serologically.

\section{Case 2}

This is the sister of case 1 . She was born at 30 weeks of gestation and died shortly after birth. A t necropsy the infant was noted to be hydropic with hepatomegaly $(104 \mathrm{~g})$ and splenomegaly $(18 \mathrm{gm})$. The placenta was very large $(850 \mathrm{gm})$. H istologic evaluation revealed storage cells in most organs, especially the kidneys, thymus, lymph nodes, bone marrow, liver, spleen, and placenta (Figure 1). E nzymatic analysis performed on a liver sample revealed glucocerebrosidase deficiency (patient: $1.5 \mathrm{nmol} / \mathrm{h} / \mathrm{mg}$ protein; fetal control: $51 \mathrm{nmol} /$ $\mathrm{h} / \mathrm{mg}$ protein) and also allowed a retrospective diagnosis of case 1 .

\section{Case 3}

This $1900 \mathrm{~g}$ boy was born at 36 weeks of gestation to a G ravida 1 Para 0 D utch mother. The father was from Surinam. A Cesarean section was performed due to fetal distress, and A PG A R scores were 5 and 7 at 1 and $5 \mathrm{~min}$, respectively. The infant had dysmorphic features including a triangular face, small malformed ears, a small thorax, joint contractures and severe microstomia. Hepatosplenomegaly was found on examination and confirmed by ultrasound. Collodion-like skin covered the entire body and was friable (Figure 2a-c). The infant was immobile except upon painful stimuli and was hypertonic with an absent Moro reflex. A cranial ultrasound revealed no structural abnormalities. Thrombocytopenia was noted. Gaucher disease was immediately considered and was confirmed by the deficiency of glucocerebrosidase activity in leukocytes (patient: $0.6 \mathrm{nmol} / \mathrm{h} / \mathrm{mg}$ protein; control range: $4.8-12$ ) and the virtual absence of activity in fibroblasts

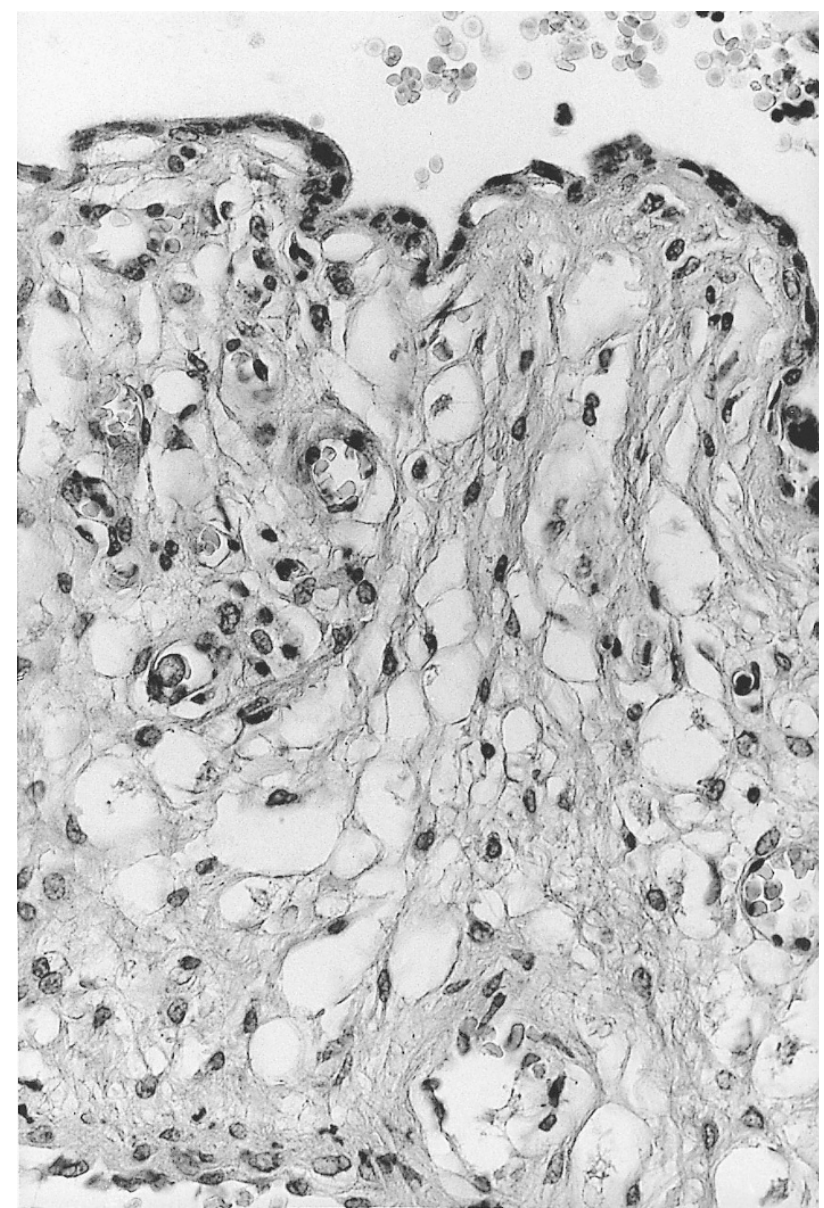

Figure $1 \mathrm{H}$ ematoxylin and eosin stained section of a placental stem villi, taken from case 2 , showing abundant $G$ aucher cells (X 65)

(patient: $\quad 0.4 \mathrm{nmol} / \mathrm{h} / \mathrm{mg}$ protein; control range 120-400). A skin biopsy revealed the characteristic epidermal ultrastructural abnormalities previously described in type 2 Gaucher disease (Figure $2 \mathrm{~d}$ ). ${ }^{10,11}$ The parents refused a postmortem evaluation when the infant died at four weeks of age.

\section{Materials and Methods}

Patient Samples

Pathology specimens were obtained at necropsy from cases 1 and 2. Fibroblast cell lines were grown from skin biopsies of case 3 and of the parents of cases 1 and 2. A skin biopsy sample from case 3 was also analyzed by electron microscopy as described. ${ }^{10}$

\section{Identification of Mutations}

Genomic DNA was extracted from cultured fibroblasts of the parents of cases 1 and 2 and the proband in case 3 . The DNA was initially screened for the presence of common Gaucher 


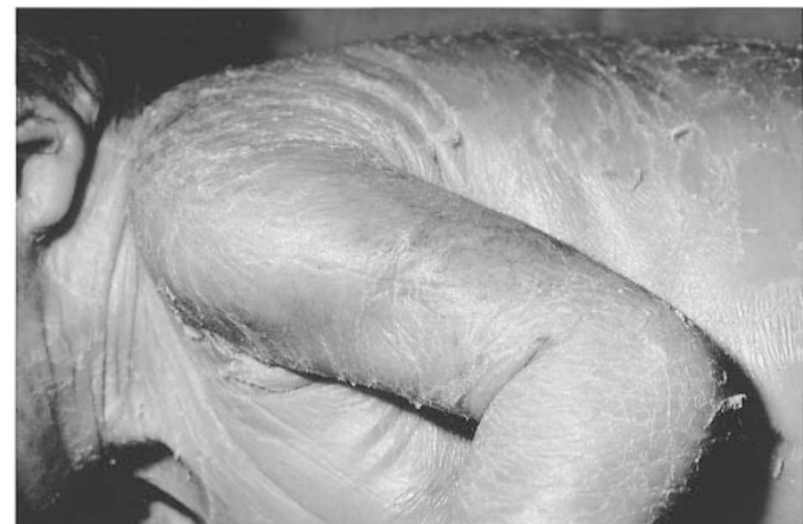

(a)

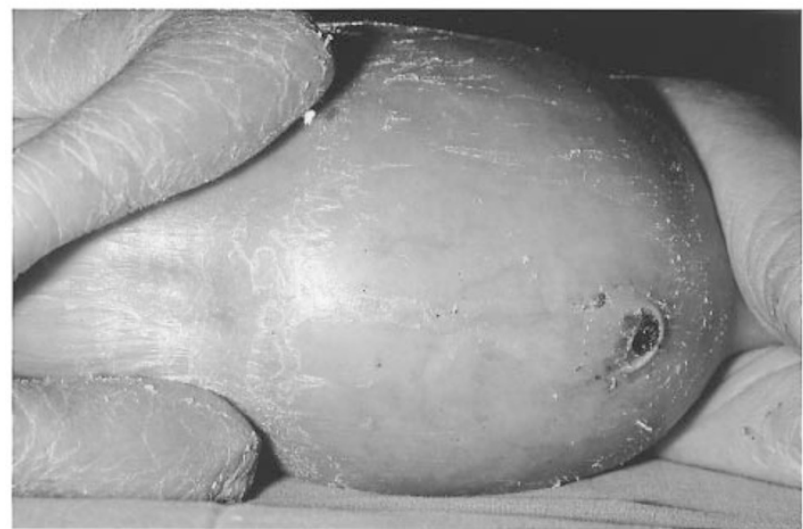

(b)

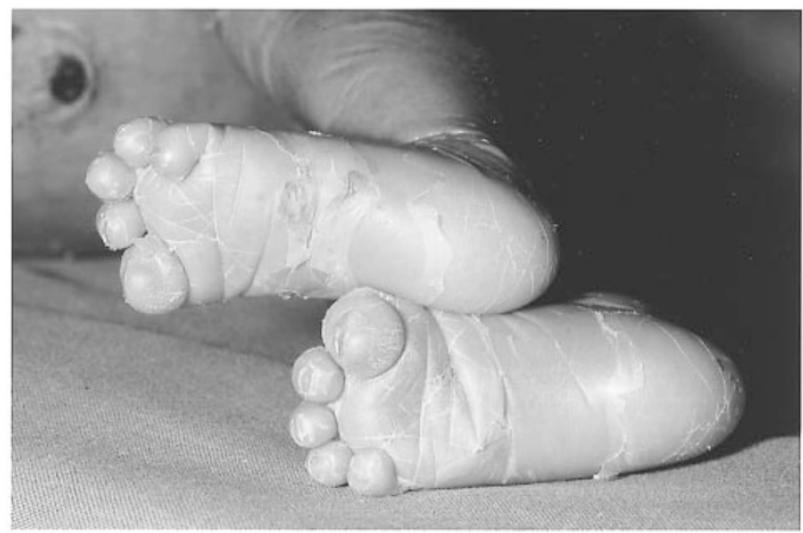

(c)

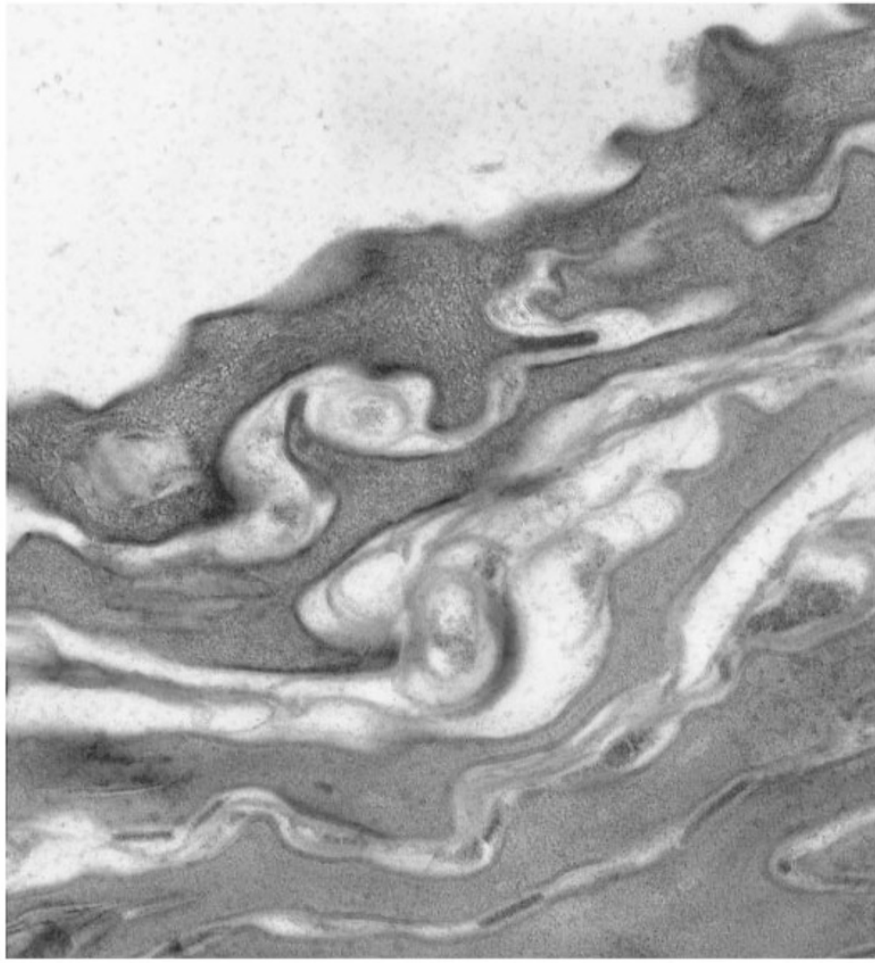

(d)

Figure 2a, b, c Case 3, demonstrating the collodion skin. 2d Electron micrograph of the skin of case 3, showing an abnormal lamellar bilayer structure (X 75,000). Tissue was post-fixed in $1 \% 0$ smium tetroxide in $0.1 \mathrm{~m}$ cacodylate buffer

mutations as previously described. ${ }^{5}$ The complete glucocerebrosidase gene was amplified by long template PCR ${ }^{12}$ to look for large deletions and recombinant alleles such as fusion genes. The 11 exonic regions including flanking intronic sequences were then selectively amplified using primers complementary to the functional gene but not the pseudo- gene. ${ }^{7}$ Several exons were amplified as a single PCR product which was then sequenced with primers specific for each exon. The PCR reactions were prepared in $100 \mu \mathrm{l}$ volumes containing $400-1000 \mathrm{ng}$ of genomic D NA , $1 \mu \mathrm{l}$ of each $20 \mathrm{~mm}$ primer, $10 \mu \mathrm{l}$ of $10 \times$ PCR buffer, $8 \mu \mathrm{l}$ of $2.5 \mathrm{~mm}$ dNTPs, and $0.4 \mu \mathrm{l}$ Ex-Taq polymerase (TaKaRa Biomedicals, Japan). 
DNA sequencing, using the fluorescent dideoxy termination method, was performed with forward and reverse primers on both strands using the 373A DNA sequencer (A pplied Biosystems, Foster C ity, CA , U SA ). The mutations identified, $H 311 R, R 359 X$, and V 398F, were subsequently confirmed by restriction digestions using the restriction enzymes $M$ ael I, Sau3A I, and Hinc II, respectively.

\section{Results}

Sequencing of genomic DNA identified the mutant alleles which are summarized in Table 1 . Restriction enzyme digests were used to confirm the presence of the mutations.

\section{Discussion}

The four cases of lethal type $2 \mathrm{G}$ aucher disease identified in one medical center emphasize the need for a full diagnostic evaluation in cases of fetal hydrops, organomegaly or collodion-like skin abnormalities. The diagnosis of G aucher disease was not made in case 1 until a second affected sibling, case 2 , was recognized as having $\mathrm{G}$ aucher disease at autopsy. Increased awareness of neonatal Gaucher disease led to an early diagnosis in case 3. Thus an appreciation of this severe phenotype can promote an earlier diagnosis and more specific genetic counseling.

The genotypes identified in the cases described are unique and interesting. The parents from the Cape Verdean family share the previously undescribed exon 8 mutation, H311R, which appears to be severe. The genotype of the collodion baby (case 3 ) is $R$ 359X/V 398F. R 359X, also located in exon 8, results in an early stop codon and was previously described in a type 2 patient (genotype R 359X /L 444P) and also in two severe type 1 patients whose genotypes include a mild mutation, N $370 \mathrm{~S} .{ }^{13}$ The $\mathrm{V} 398 \mathrm{~F}$ mutation has not been described before. These novel genotypes confirm our previous observations that there are numerous genotypes resulting in type $2 \mathrm{G}$ aucher disease and that there is genotypic heterogeneity even among cases with the

Table 1 M utations identified

\begin{tabular}{llll}
\hline Case & $\begin{array}{l}\text { G lucocerebrosidase } \\
\text { mutations }\end{array}$ & Exon & $\begin{array}{l}\text { Restriction site } \\
\text { altered }\end{array}$ \\
\hline 1 and 2 & H 311R & 8 & + M ael I \\
& H 311R & & \\
3 & R 359X & 8 & - Sau3A I \\
& V 398F & 9 & - H incl I \\
\hline
\end{tabular}

most severe phenotypes. ${ }^{7}$ Since great genotypic heterogeneity exists, enzyme analysis remains the method of choice to establish the diagnosis in patients suspected of having $\mathrm{G}$ aucher disease.

The perinatal presentation of $\mathrm{G}$ aucher disease is considered very rare. ${ }^{14} \mathrm{H}$ owever, this may not actually be true. The number of cases may be greatly underestimated because of cases that have been misclassified as collodion babies or hydrops of unknown or infectious origin, such as case 1 . The incidence of specific lysosomal disorders during the past 27 years has been estimated by combining data from all of the Clinical Genetic Centers in the Netherlands-(B Poorthuis, A Groener, R Wevers personal communication, 1998). A total of ten cases of type 2 Gaucher disease were identified. Five of the cases were 'classic' type 2 Gaucher disease, and five cases were the perinatal lethal form, suggesting that the latter may be a relatively common type 2 phenotype. $M$ any cases of perinatal lethal Gaucher disease may still go undiagnosed, as genetic causes of hydrops fetal is or congenital ichthyosis are often considered only after more than one affected child is born to a family. $O$ bstetricians and neonatologists can improve diagnostic accuracy in cases of fetal hydrops by employing early prenatal testing to assay for glucocerebrosidase activity. Skin biopsies for cell culture and ultrastructural studies, frozen tissue samples for biochemical and molecular studies, and obtaining consents for autopsies can facilitate the diagnosis after delivery. A dditional histochemical and molecular studies of the central nervous system in similar cases may lead to a better understanding of the neuropathology of the disease.

A Ithough there appears to be a cluster of patients in Rotterdam, this cannot be attributed to regional differences in the incidence of the disease, since the ethnic background of the cases seen in this center was diverse. The parents of the reported cases included two of Turkish ancestry, two from Cape Verde, one of Surinam-A frican origin, and one of Dutch ancestry. $A$ similar cluster of four cases was observed in a center in A ustralia, ${ }^{1,2}$ (W Carey, personal communication, 1998), and these cases were also of mixed ethnic backgrounds. The identification of multiple cases at certain centers is most likely a direct result of a greater awareness of the perinatal lethal phenotype in these centers. Enhanced recognition of these cases by others will help to determine whether the perinatal lethal form of Gaucher disease is actually more common than classic type $2 \mathrm{G}$ aucher disease. 


\section{References}

1 Liu K, Commens C, Chong R, Jaworski R: Collodion babies with $G$ aucher disease. Arch Dis Child 1988; 63: 854-856.

2 Lipson A H, Rogers M, Berry A : Collodion babies with G aucher disease: A further case. A rch D is Child 1991; 66: 667.

3 Sidransky E, Sherer DM, Ginns EI: G aucher disease in the neonate: $A$ distinct $G$ aucher phenotype is analogous to a mouse model created by targeted disruption of the glucocerebrosidase gene. Pediatr Res 1992; 32: 494- 498.

4 Strasberg PM, Skomorowski M A, Warren IB, H ilson WL, Callahan JW, Clake JTR: Homozygous presence of the crossover (fusion gene) mutation identified in a type II Gaucher disease fetus: Is this analogous to the Gaucher knock-out mouse model? Biochem Med M etab Biol 1994; 53: 16-21.

5 Sidransky E, Tayebi N, Stubblefield BK et al: The clinical, molecular, and pathological characterization of a family with two cases of lethal perinatal type $2 \mathrm{G}$ aucher disease. J M ed G enet 1996; 33: 132-136.

6 Tayebi N, C ushner SR, K leijer W et al: Prenatal lethality of a homozygous null mutation in the human glucocerebrosidase gene. A m J M ed G enet 1997; 73: 41-47.

7 Tayebi N, R eissner KJ, Lau EK et al: G enotypic heterogeneity and phenotypic variation among patients with type 2 G aucher disease. Pediatr Res 1998; 43: 571-578.
8 Frederickson DS, Sloan HR: G lucosylceramide lipidoses: Gaucher's disease. In: Stanbury JB, Wyngarden JB, Frederickson DS (eds). The M etabolic B asis of Inherited D isease. M CG raw-H ill International B ook Co: N ew Y ork, 1972, pp 730-759.

9 Tybulewicz V, Tremblay ML, L aM arca ME et al: A nimal model of Gaucher's disease from targeted disruption of the mouse glucocerebrosidase gene. Nature 1992; 357: 407-410.

10 Holleran WM, Ginns EI, Menon G et al: Epidermal consequences of $\beta$-glucocerebrosidase deficiency: Permeability barrier alterations and basis for skin lesions in type 2 Gaucher disease. J Clin Invest 1994; 93: 1756-1764.

11 Sidransky E, Fartasch M, Lee RE et al: Epidermal abnormalities may distinguish type 2 from type 1 and type 3 G aucher disease. Pediatr Res 1996; 39: 134-141.

12 Tayebi N, Cushner S, Sidransky E : Differentiation of the glucocerebrosidase gene from pseudogene by long-template PCR : I mplications for $\mathrm{G}$ aucher disease. A m J H um G enet 1996; 59: 740-741.

13 Beutler E, G elbart T: Two new Gaucher disease mutations. $\mathrm{H}$ um $\mathrm{G}$ enet 1994; 93: 209-210.

14 E rikson A, B embi B, Schiffmann R: Neuronopathic forms of $\mathrm{G}$ aucher's disease. Baillière's Clinical $\mathrm{H}$ aematology 1997; 10: 711-723. 